\title{
Small scale fisheries and the community: an alternative perspective
}

\author{
David Symes $^{1}$
}

Received: 11 November 2020 / Accepted: 16 November 2020 / Published online: 14 December 2020

(C) The Author(s) 2020

I have long been in awe of sociologists and social anthropologists who through long periods of study living in the community are able to conjure up something of its inner organisation, interpersonal relations, beliefs and values that shape the inhabitants' behaviours and ambitions. And I have been more than happy to use their findings to support my own research. Hence, I was delighted to read Svein Jentoft's Life above water, an illuminating re-evaluation of the close relationship between community and small scale fisheries. My concern is whether that relationship will prove robust enough to withstand the pressures of modern fisheries management. Here, I assume the role of the devil's advocate to suggest that what may be at risk are the community values, not the small scale fisheries.

Throughout the developed world, processes of globalisation, economic rationalisation, urbanisation and demographic transition have conspired to undermine the economic rationale of small scale fisheries and threaten their social reproduction. Fisheries policy has compounded the problem and the changing perspectives of the fishing community are captured in Ross' 2015 paper on 'communities of the mind'. No longer an occupation of necessity, small scale fisheries have become an endangered species without the protected status conferred by government. Governments are seldom comfortable in their handling of the small scale sector. In part, this is because fisheries are treated as a resource management issue, where rules are framed by concerns for biological sustainability and economic efficiency but small scale operators do not conform to the norms of 'economic man'. Other than being 'small', there is no single set of circumstances that adequately defines the sector; the very diversity of species, métiers and participation levels makes them appear 'unmanageable'. Small scale fisheries are thus a source of embarrassment to governments, often regarded as 'too small to matter' and treated with benign

David Symes

dg@dgsymes.karoo.co.uk

1 University of Hull, Hull, UK neglect. Wiser counsels may lead to devolving responsibility for management of inshore waters - the essential habitat for small scale fisheries - to local authorities acting in collaboration with the fishing community in a co-management approach.

Most coastal states have failed spectacularly to secure fishing rights for present and future generations. One reason is the almost universal adoption of quota as the means of allocating fishing shares in the total allowable catch and as an easy way of regulating fishers. The assumption of quota as a perpetual right led increasingly to its transferability through sale or lease. Hardin's 1968 paradigm for solving the 'tragedy of commons' is thus fulfilled through privatisation of fishing rights. Only a few states have so far opted for formal adoption of market-led rights based management; in these cases small scale enterprises are excluded, and legal constraints prevent quota transfer out of the sector. Many more states are content to allow quota transfers to occur informally and for local, regional or national self-governing bodies to assume operational control.

Among the growing literature on the socio-economic impacts of modern quota management, Dobeson (2018) has a particular resonance in its focus on the changing relationships between small scale fisheries and the local Icelandic community, occurring in a 'new and volatile culture of liberal rural capitalism'. He describes the 'disentangling' of small boat fisheries from their traditional moorings in the local community and their 'reentangling' within the relational networks of international capital, resulting from the establishment of separate ITQ systems for the small boat sector and the emergence of a fully digitalised national fish auction. Together, they provide the catalyst for the downsizing of Iceland's small boat fleet, severance of ties to local processors, a new dependency on financial institutions for investment to improve the boat's performance and a shift in behaviour from risk avoidance to risk taking in the more competitive market environment.

Breaking the link with local processors may have more than a symbolic significance for the 'disentangling' of small scale fishers from dependence on the community. Closure of the plant would have wider implications for the economic 
sustainability of the community in terms of employment and income generation. Most small boat fishers will continue to live in the same communities in order to enjoy the benefits of familiar social networks. Providing local fishing grounds continue to yield good harvests, the newly 'independent entrepreneur' would be foolish to sacrifice advantage of local ecological knowledge and access to community resources in times of emergency. Where becoming an 'independent entrepreneur' may have relevance is in relation to certain defining characteristics of community outlined in Svein Jentoft's paper. While the sense of belonging, networking and security may be unimpaired, the individual fisher may at times feel conflicted by differences of opinion in interpretation of the moral code over rules governing fishing behaviour, estranged from the community's view on security of tenure for fishing rights and somewhat alienated by the notion of a 'willingness to sacrifice freedom'.

Elsewhere in Europe, attention has focused on the endogenous development of small scale fishing enterprises. In the European Union's funding mechanism to support fishing, provision has recently been made for fishing local action groups to design programmes to increase their viability through closer integration with the local economy and create synergies with other interest groups to enhance local cultural and physical environments. To date, over 300 local action programmes, involving several thousand projects, have been activated with schemes ranging from direct sales of catch through weekly deliveries or 'farmers' markets', collaboration with restaurants to promote gastro-tourism based on locally sourced seafood and new processing firms producing 'place of origin' specialities to setting up business training groups, new heritage projects and action programmes to improve water quality for the benefit of fishing and water-based recreation. Van der Walle et al. (2015), using the example of the Pays d'Auray FLAG in Brittany, point to its achievements in strengthening the profile of the local fishing industry creating a structuring agency for the local seafood sector and building linkages with the business communities. FLAGs thus serve to rebuild esteem among small boat operators, release their latent entrepreneurial potential and re-embed them more securely within the wider community.

\section{Compliance with ethical standards}

Conflict of interest The author declares that there is no conflict of interest.

Open Access This article is licensed under a Creative Commons Attribution 4.0 International License, which permits use, sharing, adaptation, distribution and reproduction in any medium or format, as long as you give appropriate credit to the original author(s) and the source, provide a link to the Creative Commons licence, and indicate if changes were made. The images or other third party material in this article are included in the article's Creative Commons licence, unless indicated otherwise in a credit line to the material. If material is not included in the article's Creative Commons licence and your intended use is not permitted by statutory regulation or exceeds the permitted use, you will need to obtain permission directly from the copyright holder. To view a copy of this licence, visit http://creativecommons.org/licenses/by/4.0/.

\section{References}

Dobeson, A. 2018. Economising the rural: How new markets and property rights transform rural economies. Sociologia Ruralis 58 (4): 806-908.

Hardin, G. 1968. The tragedy of the commons. Science 162: 1243-1248.

Ross, N. 2015. Understanding the fisheries 'community': Bringing the social into fisheries policy through shared communities of the mind. Sociologia Ruralis 55 (3): 309-324.

Van der Walle, G., S. Gomes da Silva, E. O'Hara, and P. Soto. 2015. Achieving sustainable development of local fishing interests: The case of Pays d'Auray FLAG. Sociologia Ruralis 55 (3): 360-377.

Publisher's note Springer Nature remains neutral with regard to jurisdictional claims in published maps and institutional affiliations. 